\title{
ANALYSIS OF THE MANAGEMENT SKILLS REQUIRED OF LEADERS OF PROJECT TEAMS USING THE ANALYTIC HIERARCHY PROCESS METHOD (AHP)
}

\begin{abstract}
This paper, based on a master's thesis, provides a definition, description and the importance of effective leadership within project management. The paper describes the principles for effective leadership within project management, the function of leadership and contrasts different leadership theories, as well as the effects of the different types of leaders in organizations. The paper provides an analysis of theories that dictate the effectiveness of leadership and how effective leadership in project teams influences a range of other variables. The paper utilizes the AHP method (hierarchical analysis process) to show the priority of management skills within a project management domain.
\end{abstract}

Keywords: analysis of the management skills, leaders of project teams, AHP method (hierarchical analysis process).

\section{INTRODUCTION}

In the course of history, leaders who are able to persuade, guide, transform and motivate others to achieve objectives of common interest have emerged. However, in the 20th century, formal leadership studies began, mainly for people in leadership positions.

A person can act as a leader of a group without being a manager, however, it will be difficult to be an effective directive if he is not, at the same time, a leader of his team and of the people he manages (Palomo, 2000). Leaders are necessary in any group of people, there must always be someone who sets correct guidelines formally or informally, or else the objectives that have been set may not be met or responsibilities may be avoided. For this reason, the need to continue studying and analysing this concept is still evident today, as leadership has become a key element in the economic development of society.

According to Warren Bennis (Bennis, 2003) it is necessary that any group of people be led by someone who guides, motivates and facilitates the execution of the tasks. Therefore, leaders must know how to interact effectively with their environment, increasing the chances of successfully managing the projects they lead.

${ }^{1}$ Nuria Muñoz Vila. Master in project management. Higher Technical School of Industrial Engineers, Polytechnic University of Valencia. ORCID: 0000-0002-8908-935X.

2 Jacek Strojny, DSc PhD. Associate Prof. The Faculty of Management, Rzeszow University of Technology, al. Powstańców Warszawy 10, 35-959 Rzeszów; e-mail: jstrojny@prz.edu.pl (corresponding author). ORCID: 0000-0003-4632-8645. 
People, as social beings, need to interact with others to achieve their goals. So, we need to work in a team. Teamwork has many advantages for both the organization and the individual:

Advantages of teamwork in the organization (Vera, José, 2011):

- Higher level of productivity.

- More effective communication.

- Greater commitment.

- Better work environment.

- Easier to carry out complex tasks.

- Facilitates the direction, supervision and control of tasks.

- Facilitates integration.

- Facilitates internal and external coordination.

- Greater satisfaction.

Advantages of teamwork in the individual (Vera, José, 2011):

- Need for affiliation.

- Personal security.

- Personal and professional development.

- Stimulation for creativity.

Although teamwork can also lead to problems at work. Sometimes it can be more time-consuming, and one individual or subgroup can control or manipulate the rest. There are also processes that negatively affect the quality of group work with the diffusion of responsibilities and group thinking. So, there may be a rejection of certain team members and sometimes lead to lower productivity.

Therefore, this process requires a good handling of the positive and/or negative feelings that may arise, so that they do not intervene in the achievement of the objectives proposed by the project. This requires a good leader.

In the development of a project, in a team led, conflicts arise that lead to decisions that positively or negatively affect the relationship between team members, productivity, quality of work and customer service. Conflict resolution depends largely on the type of leadership exercised on the project.

Leading a group of people requires special skills. Not all people have the same capacity to be leaders and contribute to the development of the organization. That is why there are people dedicated to being project leaders.

The success of an organization is strengthened by the right behaviour of both managers and employees. Leadership can transform a simple worker into a valuable team member. The leader's ability can change an employee's mindset into an owner's one. Employees who believe that they have a direct relationship with the organization generally find ways to improve their attitude and productivity to get the best results.

Leadership and human talent management are of paramount importance to organizations. This depends largely on their effectiveness and productivity. The talent gathered in a company must work in a synchronized, proactive, intelligent and adding value and innovation. In this document, we will show the most relevant ones in terms of leadership, from its definition, through types of talents, characteristics of a good leader and other aspects that, in my opinion, are valid for the development of this research topic.

In order to understand the importance of this position, it is significant to know how to define it. Leadership is the influence exerted on people to encourage them to work 
enthusiastically for a common goal. (https://definicion.de/liderazgo) The leader is a person who stands out from the rest and is able to make good decisions for the group, team or organization he or she leads, inspiring the rest of the members of that group to reach a common goal. It is also important to define human talent management. It is understood as the space that companies provide to attract, motivate, retain and develop the most competent, capable and committed professionals and, above all, with the ability to convert individual talent, through a project. This talent is a committed professional to put into practice his abilities to obtain superior results in a determined environment and organization. There are different types of talents: commercial talent, managerial talent, leading talent, technical talent, administrative talent, among others. The innovator and the entrepreneur are added, which is the one that adds the greatest value to the company.

To adapt to the constant change in the world, leaders must be prepared to innovate. For this, organizational leadership is essential, the leader's ability to guide in all areas, the achievement of objectives and the satisfaction of the company's needs.

The true leader must have the ability to inspire passion and enthusiasm, control his own emotions and enhance positive feelings in the teams. The role that leaders play is valued today more than ever, as the direct influence on the performance and results of organizations can be measured and proven. A good leader must know what his strengths and weaknesses are, know what he wants, why he wants it and how to communicate it to others. Leadership skills are necessary to establish motivating work environments that allow employees to grow and develop (Thomson, 2012).

According to a study conducted by senior executives and subject matter experts from ESI International, one of the key aspects in any methodology, whatever its nature, is leadership.

A successful company needs good leadership. The company must establish a clear vision of the projects, know how to communicate it to the participants, and have a correct way to resolve conflicts. Nowadays, organizations are looking for good managers who also have the ability to motivate employees. A company's survival depends on the leader's ability to carry out the proposed objectives. The organization can create good planning, but a lack of leadership can cause it to succumb, and even if the organization lacks planning, a good leader can do it. If the organization wants to achieve high levels of productivity of human capital, the development and strengthening of leadership is essential.

\section{MAIN CHALANGES OF THE CONTEMPORARY PROJECT MANAGEMENT}

For the correct functioning of the management of a project, the project teams are characterized by the definition of clear objectives, shared by all its members, which serve as a guide for action. This is a fundamental difference from a working group, in which the common objective does not always exist. This common objective determines a common final destination for the project team, so that all team members feel responsible, to a greater or lesser extent, for the success or failure of the project.

According to the Project Management Institute (PMI) a project is "a project is a temporary effort that is carried out to create a unique product, service or result"; it is a planning that consists of a set of activities that are interrelated and coordinated.

The project management division can be divided into four distinct phases: (The 4 Phases of the Project Management Life Cycle, Posted by Lucidchart Content Team, August 28, 2017) Initiation phase, planning phase, axecution phase and cloure phase. In the first phase 
the activities to be carried out will be those of the search for new ideas and opportunities, the search for external contacts and support in new ideas. In the second phase of analysis we should finish the tasks and consult the critical and impartial judgment on the different options and opportunities. In addition, we should avoid being overly critical and not get carried away by group thinking. In the third phase of action, you must correctly design the different points to be made. The whole team has to participate and get involved. In this phase, we must avoid forgetting the main objective, inefficiency, and we must not implement plans that are not completely elaborated. The final phase of a project will aim to verify that the work done has been adjusted to what was planned. The reflection demanded by the closing will also serve to draw conclusions to learn, in such a way that it will allow to highlight successes and errors. This knowledge will be very important for future projects.

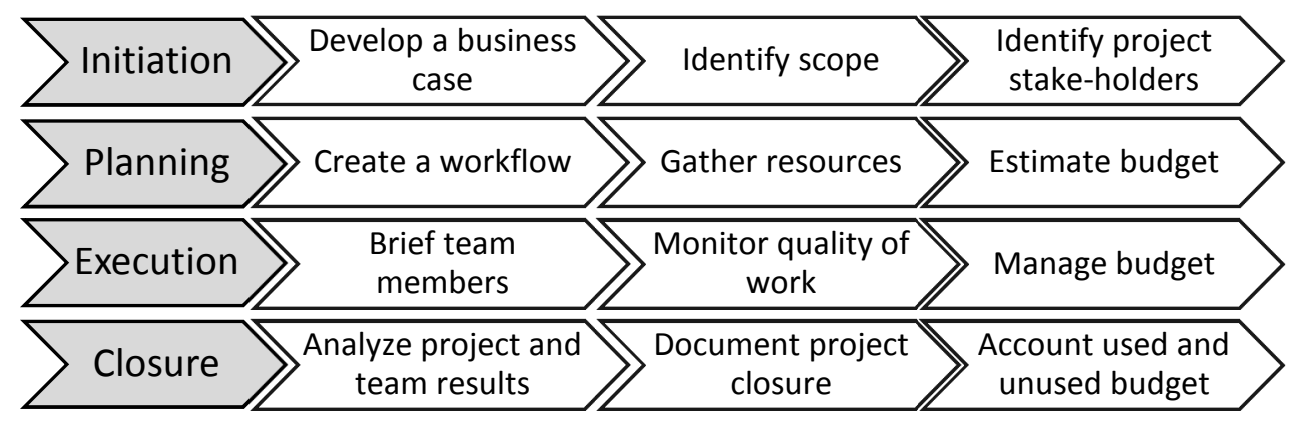

Fig. 1. The 4 Phases of the Project Management Life Cycle. Posted by Lucidchart Content Team, August 28, 2017

One of the main challenges of good project management is that everyone involved in the project is motivated. This is a key element for the development of a project. Motivation refers to the forces that cause a person to engage in work-related behaviour and that determine the form, the direction, the intensity and the duration of the efforts. This motivation can occur in two ways, intrinsically: derived from the task itself or from a sense of duty, or extrinsically: derived from the reward to be obtained.

For the challenges faced in managing a project to be done properly, an effective team led by a good leader is needed. This leader will lead an effective team characterized by (McGregor, Douglas, 1960):

- An informal, comfortable and relaxed atmosphere.

- If there is a discussion, the whole team participates. Only if this discussion is relevant to the task.

- The task or objective of the team is understood and accepted by the team members, although they may come to agreements where a whole discussion process has been necessary. It should be formulated in such a way that the whole team can be involved.

- The people who make up the team listen to each other. No one should be afraid to make a proposal, even if it may be extravagant.

- There are disagreements. These are examined from different points of view and the team tries to resolve the discrepancies. 
- Most decisions must be made by consensus. Voting is only done in special circumstances. The team should not accept a simple majority as a basis for action.

- Criticism is common, but there are no personal or covert attacks.

- People should feel free to express their ideas and opinions.

- Tasks must be clearly defined

- The leader does not dominate the team.

Then the leaders must be able to motivate and convince their team about the object and purpose of the project and can reduce the natural deviations and known uncertainties that occur. A common mistake is to take as project leaders' people with a deep scientific knowledge, but with a lack of business vision.

The key success factors of a project team for proper management are when project teams are properly led by a good leader. Increasing the motivation of its members, improving productivity and achieving more effective solutions to problems.

Here are some features that are repeated in the winning project teams (Chiocchio, François, Kelloway, Brian Hobbs, 2015):

- These teams know what they're doing, and their members agree with the goals they set.

- Individual team members act freely and creatively, talking when they disagree or asking when they don't understand something, without feeling it is a personal matter.

- Team members bring different knowledge and share it with the group.

- There is a feeling of belonging to the team that engenders mutual trust and support among its members.

- The team's standards and rules are transparent and clear so that all team members understand them and decision-making in the team is participatory.

- They regularly spend time checking the "health" of the team, taking inventory and asking themselves "how are we doing?".

It is important to say that the way in which the team is led sets the tone for all project activities. Therefore, the way to manage each of the six aspects mentioned previously will contribute to strengthen or destroy the team. Therefore, the fundamental task of project managers is not only to manage the effort of their team, but to lead its members to achieve the success of the venture.



Fig. 2. Good leader (own creation) 
Some theories claim that leaders can be recognized by their personality and base this claim on the belief that leaders are born and not made, so the ability to lead is an innate characteristic of the individual. According to this research, leaders tend to be intelligent, flexible and self-confident people. But they are also characterized by their knowledge of the exact tasks they perform, the energy of work they demonstrate and their ability to motivate others.

However, other theories, like a new study from the University of Illinois that supports the idea that leaders, not born, are made; and that leadership development follows a specific progression. So hold the opposite position to the previous one and proclaim that leaders are not born but made. Starting from this premise, they concentrate on the study of leaders behaviours and their influence on the performance of their followers.

\section{ELEMENTS THAT CONTRIBUTE TO FORM AN EXCELLENT ORGANIZATIONAL LEADER}

Its main objective is to guide the will of the team members, optimizing the results at the group level. The leader must know each of the members and guide them towards achieving the objectives of the proposed group; encouraging communication between them, detecting their strengths and weaknesses, identifying opportunities for improvement in the short and long term. For this, the leader must put into practice his or her social skills, which allow him or her to communicate effectively with his or her team. He must be empathetic and ensure that employees do not work individually, but for the welfare of the group and the organization.

Strategic human talent management requires leaders to have accurate information about what each member of their team can contribute and the commitment of the rest of the team members to the business project. Therefore, leaders can develop efficient management styles, collaborative strategies and internal communication.

In the modern field of business, organizational psychology has implemented the Theory of the Enneagram (or personality map) (Reynolds, 2007) that offers nine types of personalities or neotypes, to identify each member of the team and know why each person reacts and interprets reality differently. This is used for the application of leadership styles and preparing teams related to the strengths of each leader. Just as there are people who react negatively, there are also people who argue positively and do not allow language to become aggressive or violent. However, the most common behaviour is that people prefer to react with silence, for fear of losing their job or creating uncomfortable situations in the near future. However, this attitude motivates the superior to repeat the behaviour and become an alternative for management to work. Calling attention is, besides a skill, an opportunity to improve management and develop a better working relationship and make the employee a person capable of assuming the consequences of his actions without fear of feeling disqualified in front of his colleagues.

Personal conversation is best, in a climate of closeness and trust, in private, so that the other party can be heard. This theory of the Enneagram allows us to predict which situations can cause stress to each personality type, how to compensate for it and how to function under working conditions under pressure to achieve maximum performance. This tool makes it easier for leaders to strategically manage their teams based on their deepest knowledge. 
The leader must know how to attract attention and not affect the work environment negatively. This capacity is not easy to develop, and even less so if it occurs in the heat of circumstances that require urgent intervention and must be corrected urgently. Calls for attention are part of the management process. Part of the credibility, respect and trust towards the leader is born precisely from the way in which corrections and calls for attention are made.

In a private meeting a good leader must avoid conflict, clarify misunderstandings and give the opportunity to accept or rectify the action that motivates the call for attention. However, precautions must be taken, as leadership can have a negative impact on company performance. Leaders who are too dominant or obsessed with some objectives may ignore some details in the organization. It may also be that managers and/or employees are unwilling to help dominant or extremely critical leaders, the boss who shouts and insults is creating all the conditions for poor results.

Just as there are factors that facilitate teamwork, there are also factors that hinder it (Ignacio Martínez, Blog.):

- Ignorance of teamwork.

- Lack of time.

- High sanitary pressure.

- Ignorance of roles and functions.

- Ignorance of the organization's mission, objectives and goals.

- On the part of the leader being dominant, with an attitude of superiority towards the group.

- Not being able to maintain the interest and adherence of the group.

- Team members who do not participate. They stagnate, do not grow and therefore do not support their colleagues and the leader.

- Existence of a systematic opponent.

- The formation of subgroups; when they interfere with the functioning of the team.

- Failure to recognize the leader as such.

- Very incomplete team.

- In many teams, the low commitment of some sectors or departments.

A leader needs collaboration at all levels; he or she must have enough support to get results. The leader must be aware that the impact of his or her decisions can be successes or mistakes that can damage trust and, therefore, the aspirations for growth.

A leader needs collaboration at all levels; he must have enough support to get results. The leader must be aware that the impact of his or her decisions can be successes or mistakes that can damage trust and, therefore, the aspirations for growth. To avoid making some mistakes, it is important to identify them and take steps to correct them.

Some of these mistakes are:

1. Self-critical leadership. In certain cases, if people are not willing to collaborate, a firm leader is needed, but if people are willing to help, this self-critical attitude affects the leader's management, creating an atmosphere of discomfort and pessimism and of carrying out the activities to be carried out. Some cases in which the leader's attitude affects the process, can be positive and negative feelings must be handled properly so that they do not interfere with the desired results. The interaction between co-workers is not always the desired one. This can lead to positive or negative decisions that affect productivity and quality of work. 
- Ask for the opinion of experts and knowledgeable people and do not take them into account when applying them.

- Keep all information on what is to be done and keep staff in line, it can mean lost opportunities and staff remaining in a permanent comfort zone.

2. Human talent management is wasted. The leader is so dedicated to the task and results that human talent development is neglected.

- The staff needs to be heard, can give ideas and / or have information that is relevant to project development.

- Focus only on mistakes and neglect other activities that lead to the achievement of objectives.

3. Paralysis to change, to innovate. Sometimes, if something went well before, it would be worth repeating.

4. Unilateral decision making. Limiting the formation of future leaders. People need to know how to do their job and make decisions.

5. Communication failures. The leader assumes that the messages given were understood by everyone. In stages of change and/or crisis, the "radio pallet" is created, that is, the information is not clear enough because it creates alternative communication that causes confusion and alters the work environment.

6. Immediate results. Lack of long-term focus. The faster the results are obtained, the less stress there is and the better it is for the organization, but this should not allow the leader to lose his or her long-term focus. This allows the leader to know more about the market, the business and help the company grow.

7. Training as a non-priority activity. The leader must be constantly updated, must be an example for the staff that promotes its own growth.

A leader is under constant pressure, whether by objectives, customers, problems, crisis, government policies, etc. To be a leader is to learn, change, grow constantly to keep up to date and think about how it will be better in the long term. A good leader produces many positive effects. Then we can see the benefits associated with it as:

- It promotes and increases the level of communication that exists in a work group. A dynamic communication between the members of a group allows the successful completion of activities, scheduled or not. This group communication is essential to face and solve unexpected situations.

- Productivity improvement by objectives: continuous dialogue and regular meetings with each member, individually and in groups, greatly improve the achievement of expected results.

- Greater resolution of internal conflicts: it is natural that in any human team unexpected problems arise between the members and those related to the activities carried out. To neutralize them, the leader must make an interpersonal communication, listening actively to the approach of each worker.

- Optimization of the work environment: as a result of the presence, development and promotion of the previous points, the result will be to be able to carry out the daily tasks in a pleasant and suitable environment. Therefore, objectives can be achieved more effectively and efficiently.

- Higher level of work participation: with a positive leadership, an increase in the work activity of each member of the work team will be achieved. 
- A large number of people with leadership qualities are found and exercise that leadership in different ways, therefore, leadership is classified according to the method used to lead a certain group of people.

Another topic I would like to mention and that will be very useful in the process of hierarchization is that for John C. Maxwell (1999). A leader must have 21 characteristics to improve quality:

1. Character: makes him stronger. However, sometimes it has negative consequences.

2. Charisma: ability to attract people to himself. If he does not have it, he can develop it.

3. Commitment: To accomplish no matter what may come: illness, poverty or disaster, you must not take your eyes off the target.

4. Communication: sharing knowledge and ideas. People will not follow if they do not know what they want or where they are going.

5. Capacity: it is the leader's ability to say it, plan it and do it in such a way that others know that you know how to do it.

6. Courage: It is easy to see heroes in war, but courage is also present in all great leaders in business, government and church.

7. Discernment: can be described as the ability to find the root of a problem and is based on intuition and rational thought. To know which half to believe in.

8. Concentration: the key is priorities and focus. If you have concentration, but no priorities, you have excellence without progress.

9. Generosity: nothing speaks louder or serves others more than the generosity of a leader.

10. Initiative: successful people are active. They must always look for opportunities and be ready for action.

11. Listening: A good leader encourages others to tell you what you need to know, not what you want to hear. And you learn that by listening.

12. Passion: Experts spend a lot of time trying to figure out what makes people successful, but more than anything else, passion makes a difference.

13. Positive attitude: Most people who achieve lasting success in their respective professions almost always have a positive outlook on life.

14. Problem solving: No matter what field a leader is in, he will face problems. They are inevitable for three reasons. First, because we live in a world of increasing complexity and diversity. Second, because we interact with people. And third, because we cannot control every situation that arises.

15. Relationships: The ability to work with people and develop relationships is absolutely indispensable for an effective leader.

16. Responsibility: good leaders never adopt the victim's mentality.

17. Safety: no one can live on a level that is inconsistent with the way you see yourself.

18. Self-discipline: without it, no one achieves or maintains success. It doesn't matter how talented a leader is.

19. Service: the concept of servitude does not refer to positions or skills. It is about attitude.

20. Learning: If you want the organization to grow, you must continue to learn

21. Vision: For a leader, vision is everything. It is what guides him. It is the one who scores the goal. 
Although the level of leadership required will depend on both the project to be developed and the organizational structure of the entity, they must be able to develop projects with technical and economic viability, effective marketing and dissemination so that the results and benefits generated can be used by stakeholders and beneficiaries. In addition, project leaders must know aspects related to markets, operations, financing, and personnel management, which implies having a gift for people and empathy, since in most projects the work team is made up of personnel with great cultural differences.

\section{TYPES OF LEADERSHIP IN PROJECT MANAGEMENT}

The leader must know each of the members and orient them towards the scope of the proposed group objectives; encouraging communication between them, detecting their strengths and weaknesses, identifying opportunities to improve in the short and long term.

For this, the leader must put into practice his social skills, which allow him to communicate effectively with his work team. You must be empathetic and ensure that employees do not work individually, but rather for the welfare of the group and the organization (Essay Impact of Human Talent Leaders in the Organization Paula Alejandra Castro Castillo). The types of Leadership in Project Management are:

- Business leadership: Exercised by the person responsible within the company, forming a link with the workers and the company's objective, its main function is to make the company function perfectly in all areas, in search of success.

- Autocratic leadership: One person is responsible for responsibilities and decision making. Power is focused on one person and subordinates are not taken into account when making decisions.

- Democratic leadership: Carried out by one person, who takes into account the participation of all the people who make up the organization, accepts ideas and criticism for improvement, responds to any concerns of the people in his charge, and this creates trust among his subordinates, which encourages teamwork in the search for the achievement of the proposed objectives.

- Laissez faire leadership: An expression of French origin whose translation into Spanish is "let do", therefore, it is a very liberal concept; the leader is a passive figure.

- Higher level of labour participation: With positive leadership, you will achieve an increase in the labour activity of each member of the work team. The people in charge have total control of what is being done. They are given all the information and tools necessary to carry out the work and the leader only intervenes if the subordinate asks for help.

- Parental leadership: The leader takes full responsibility for guiding and ensuring the well-being of his subordinates. Use incentives with workers, offering rewards if the work is done successfully. That is why it is called paternalistic leadership, because as a parent in the home, he assumes this role in the company to generate better results at work.

- Charismatic leadership: The leader has the capacity to captivate and generate enthusiasm in the people he leads, a lot of communication with the people in charge, to give their maximum effort, to achieve the established objectives.

- Lateral leadership: Based on the belief that "any person is capable of leading a certain group of people", this type of leadership is carried out, based on experience, within a group of employees of the same level. 
- Situational leadership: Type of leadership that the boss must adopt with respect to the level of development of the employees and the situation in which they find themselves. It is quite effective, as it is exercised by the most appropriate employee with respect to the situation in which the team finds itself.

\section{METHODOLOGY OF THE MULTI-CRITERIA ASSESEMENT OF SIGNIFICENCE OF THE MANAGEMENT SKILLS SUPPORTING PROJECT LEADERSHIP}

Decision-making is the process by which one or more decisions are obtained as a result with the purpose of solving a situation.

Nowadays, in organizations, decisions are made at a strategic and tactical level, which are increasingly made by a group of people and not by individuals. Therefore, the opinion of a single person in the decision-making process is considered insufficient when analysing complex problems, especially those problems where the solution may affect many other people. In these cases there are usually several criteria that may be in conflict with each other and that require the application of Multicriteria Decision Analysis Methods (MDAM). MCDAs describe a collection of concepts, methods, and techniques that are intended to help individuals or groups make decisions involving different conflicting viewpoints and multiple stakeholders (Rodriguez, 2009). Among the MDAMs, the Hierarchical Analytical Process (HAP) developed by mathematician Thomas Saaty (1980) is noteworthy. It was designed to solve complex problems with multiple criteria and has had a wide range of successful applications in assisting business and government decision making. Moreover, this method is easy to understand and robust enough to analyse the complexities of real problems.

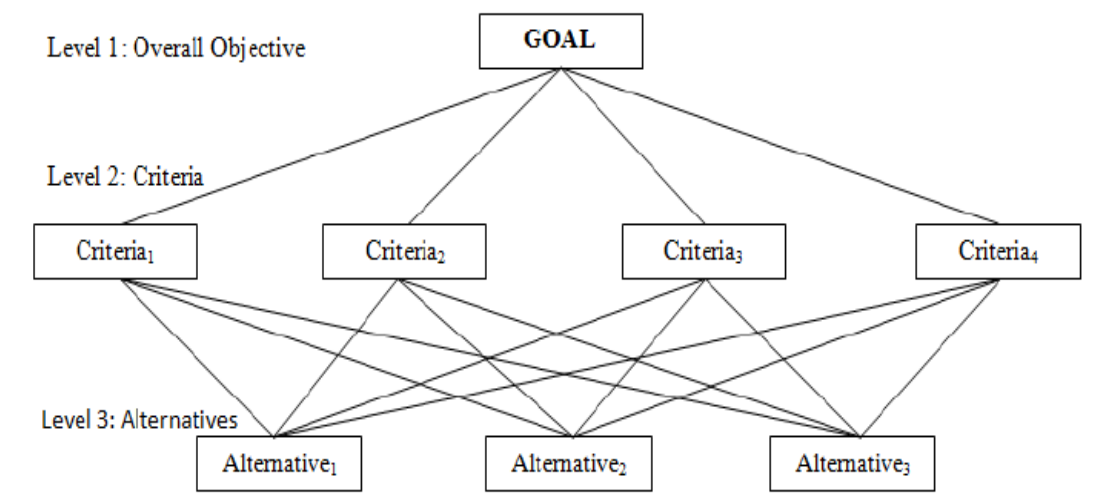

Fig. 3. Hierarchical structure in the analytic hierarch process (AHP) method. Academic notes in the subject of Decision Making in the Master of Project Management at the Polytechnic University of Valencia

This method allows for the analysis of both qualitative and quantitative factors and requires that judgments be made about the relative importance of each criterion and preferences about each decision alternative (Anderson et al., 1999). The main drawback of decision making on complex problems is finding the best solution among a set of alternatives, which are evaluated by multiple conflicting criteria and in which multiple 
decision makers participate. Thomas Saaty purpose of solving this type of problem starting from a hierarchical model of it. This model allows to divide a complex decision into a set of simple decisions, facilitating the understanding and solution of the complex problem under consideration. Figure 1 shows a generic scheme of hierarchy in which it can be seen that the superior element is the Objective or goal to be achieved. The elements of the lower level represent the various Alternatives proposed as possible solutions to the problem posed. While the intermediate levels represent the Criteria and sub-criteria (this level being optional depending on the characteristics of the problem to be analysed) through which each of the proposed Alternatives will be evaluated.

The AHP technique is essentially composed of three stages:

1. Analysis and modelling of the problem to be solved by means of a hierarchical structure in which its main elements are defined, such as the objective to be achieved by applying the AHP technique, the criteria and sub-criteria (optional) to be used for evaluating the various alternatives proposed as feasible solutions to the problem

2. Expert judgement through pair-wise comparisons These judgements reflect the relative importance, measured according to the scale (Table 1) proposed by Saaty (1980), which for the expert represents the elements of a lower level with respect to the elements of the higher level. These judgements are collected in a series of matrices of comparisons by pairs from which the local priorities of each element in the hierarchy are obtained.

3. Prioritization and synthesis. At this stage, using prioritisation procedures, global priorities are obtained for each of the alternatives identified in the hierarchical structure. This allows us to establish a ranking of the alternatives from which to confirm which of these alternatives is the best to solve the problem posed.

\begin{tabular}{lll} 
Scales & $\begin{array}{l}\text { Degree of } \\
\text { preference }\end{array}$ & Explanation \\
\hline 1 & $\begin{array}{l}\text { Equally } \\
\text { Moderately }\end{array}$ & $\begin{array}{l}\text { Two activities contribute equally to the objective } \\
\text { Experience and judgment slightly to moderately favor one } \\
\text { activity over another } \\
\text { Experience and judgment strongly or essentially favor one } \\
\text { activity over another }\end{array}$ \\
9 & Strongly & $\begin{array}{l}\text { An activity is strongly favored over another and its } \\
\text { dominance is showed in practice }\end{array}$ \\
9 & Extremely & $\begin{array}{c}\text { The evidence of favoring one activity over another is of the } \\
\text { highest degree possible of an affirmation }\end{array}$ \\
$2,4,6,8$ & Intermediate values & $\begin{array}{c}\text { Used to represent compromises between the preferences in } \\
\text { weights } 1,3,5,7, \text { and } 9\end{array}$ \\
Reciprocals & Opposites & Used for inverse comparison
\end{tabular}

Fig. 4. Points AHP. Academic notes in the subject of Decision Making in the Master of Project Management at the Polytechnic University of Valencia

Since the appearance of the AHP technique, there have been multiple areas such as: Personal, Social, Production, Policy and Management, among others. Likewise, it has been used in various applications (Selection, evaluation, assignment etc.) due to the ease of representing certain complex problems through a hierarchical structure. Another advantage 
that has facilitated its use is that it allows both quantitative and qualitative criteria to be handled at the same time.

In the area of study relating to Intellectual Capital, the application of the AHP technique is recent and few in number, as can be seen from the review of the literature. However, due to the potential of this technique, its use is expected to increase. The main applications focus on prioritizing the indicators to be used to measure various elements considered in Intellectual Capital. Since the definition and prioritization of the indicators used to measure any important business activity promotes to companies a guide of where to focus their efforts to achieve success (Bozbura 2007). Another application for which the AHP technique has been used is to determine the impact of certain intangibles on the creation of value for the company.

\section{ASSESSMENT OF THE SIGNIFICANCE OF MANAGEMENT SKILLS SUPPORTING PROJECT LEADERSHIP. HIERARCHY OF CHARACTERISTICS OF A GOOD LEADER WITH THE AHP METHOD}

In this study on leadership, many variables or attributes have been identified that can characterize these leaderships in the aforementioned contexts. For this research, in order to identify and prioritize the most relevant variables as personal characteristics of a good project leader, informants from the Valencia Polytechnic University were consulted who were asked: what are the most important characteristics (attributes) that must be present in the project leaders. From the above, 7 variables were obtained as a result:

Table 1. Skills for the determination of study attributes

\section{Good leader skills}

Adaptability: The ability to adaptability is about having ready access to different ways of thinking, enabling leaders to shift and experiment as things change. Having an elastic cognitive approach allows leaders to use different thinking strategies and mental frameworks.

Ability to lead. The ability lead is when the leader knows how to lead and delegate.

Ability to solve problems. The ability to solve problem can be defined as efficiency and agility in finding solutions to the problems that have arisen. Those people with high capacity for problem solving are able to act proactively, without wasting time, and finding the most appropriate solutions for each case, always thinking about the repercussions that they may have in the long term.

Strategic and negotiation capacity. The ability of strategic and negotiation capacity is when the leader must know how to reach a compromise or agreement while avoiding challenges and disputes. Ability to seek mutual benefit through strategies and maintaining a relationship.

Team-Work capacity. The ability of team-work capacity is the ability to actively participate in the execution of a common collective goal.

Charisma The ability of charisma is a method of encouraging particular behaviour's in others by way of eloquent communication, persuasion and force of personality. Charismatic leaders motivate followers to get things done or improve the way certain things are done.

Empathy The ability of empathy means being able to understand the needs of other team members and stakeholders.

Source: Own creation.

From these 7 variables the hierarchical structure that corresponds to establish through the AHP method the prioritization of attributes or qualities associated with leadership has been defined. 


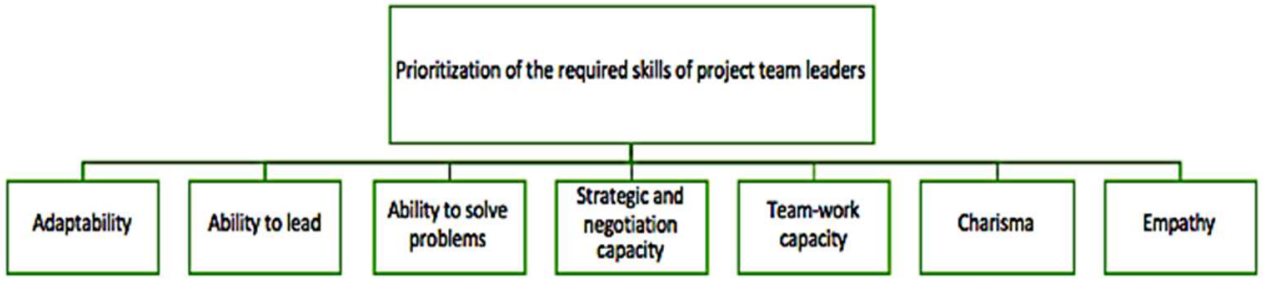

Fig. 5. AHP structure of the priority study

Source: Own creation.

To make the pairwise comparison, an expert group of 3 participants was defined. To obtain this peer comparison, the experts responded individually to a questionnaire, where: Where:

- $\mathrm{C} 1$ is Adaptability

- $\mathrm{C} 2$ is Ability to lead.

- $\mathrm{C} 3$ is Ability to solve problems.

- C4 is Strategic and negotiation capacity.

- C5 is Team-Work capacity.

- C6 is Charisma.

- C7 is Empathy.

Table 2. Example format for peer comparison

\begin{tabular}{|c|c|c|c|c|c|c|c|c|c|c|c|c|c|c|c|c|c|c|}
\hline & 9 & 8 & 7 & 6 & 5 & 4 & 3 & 2 & 1 & 2 & 3 & 4 & 5 & 6 & 7 & 8 & 9 & \\
\hline $\mathrm{C} 1$ & & & & & & & & & $\mathrm{x}$ & & & & & & & & & $\mathrm{C} 2$ \\
\hline $\mathrm{C} 1$ & & & & & & & & & $\mathrm{x}$ & & & & & & & & & C3 \\
\hline $\mathrm{C} 1$ & & & & & $\mathrm{x}$ & & & & & & & & & & & & & $\mathrm{C} 4$ \\
\hline $\mathrm{C} 1$ & & & & & & $\mathrm{x}$ & & & & & & & & & & & & C5 \\
\hline $\mathrm{C} 1$ & & & & & & & & & $\mathrm{x}$ & & & & & & & & & C6 \\
\hline $\mathrm{C} 1$ & & & & & & & & & & $\mathrm{x}$ & & & & & & & & C7 \\
\hline $\mathrm{C} 2$ & & & & & & & & & & & $\mathrm{X}$ & & & & & & & C3 \\
\hline $\mathrm{C} 2$ & & & & & & & & $\mathrm{x}$ & & & & & & & & & & $\mathrm{C} 4$ \\
\hline $\mathrm{C} 2$ & & & & & & & & & & $\mathrm{x}$ & & & & & & & & C5 \\
\hline $\mathrm{C} 2$ & & & & & & & & & $\mathrm{x}$ & & & & & & & & & C6 \\
\hline $\mathrm{C} 2$ & & & & & & & & $\mathrm{x}$ & & & & & & & & & & C7 \\
\hline C3 & & & & & & $\mathrm{x}$ & & & & & & & & & & & & $\mathrm{C} 4$ \\
\hline C3 & & & & & & & & $\mathrm{x}$ & & & & & & & & & & C5 \\
\hline C3 & & & & & & & & & & $\mathrm{x}$ & & & & & & & & C6 \\
\hline C3 & & & & & & & & & & & $\mathrm{x}$ & & & & & & & C7 \\
\hline $\mathrm{C} 4$ & & & & & & & & & & & $\mathrm{x}$ & & & & & & & C5 \\
\hline $\mathrm{C} 4$ & & & & & & & & & & & $\mathrm{x}$ & & & & & & & C6 \\
\hline $\mathrm{C} 4$ & & & & & & & & & $\mathrm{x}$ & & & & & & & & & C7 \\
\hline C5 & & & & & & $\mathrm{x}$ & & & & & & & & & & & & C6 \\
\hline C5 & & & & & & & & & $\mathrm{x}$ & & & & & & & & & C7 \\
\hline C6 & & & & & & & & $\mathrm{x}$ & & & & & & & & & & C7 \\
\hline
\end{tabular}

Source: Own creation. 
Where:

C1 is Adaptability

$\mathrm{C} 2$ is Ability to lead.

$\mathrm{C} 3$ is Ability to solve problems.

$\mathrm{C} 4$ is Strategic and negotiation capacity.

C5 is Team-Work capacity.

C6 is Charisma.

And C7 is Empathy.

Once the answers of the experts in the questionnaires attached to this document in the annex have been obtained, we have proceeded with the help of the SuperDecisions software.

The SuperDecisions is used for decision-making with dependence and feedback. This software provides tools to create and manage AHP and ANP models, enter your judgements, get results and perform sensitivity analysis on the results. It also provides support for complex, multilevel BOCR models (www.superdecisions.com).

For this they have moved their responses to the program. Including the different levels first and then including their scores.

After obtaining the individual judgments, the aggregation of group or group judgments was made using the geometric average method, obtaining the aggregate matrix. After this matrix you will calculate the relative weights of each skill and according to the result of the weights the priorities of these skills are determined. These calculations are also found in the annex.

Table 3. Final results where $\mathrm{C} 1$ is Adaptability, $\mathrm{C} 2$ is Ability to lead, $\mathrm{C} 3$ is Ability to solve problems, C4 is Strategic and negotiation capacity, C5 is Team-work capacity, C6 is Charisma and $\mathrm{C} 7$ is Empathy

\begin{tabular}{|l|l|l|l|c|}
\cline { 2 - 5 } \multicolumn{1}{c|}{} & Expert 1 & Expert 2 & Expert 3 & Geometric Mean \\
\hline C1 & 0,08301 & 0,08377 & 0,05881 & 0,07423 \\
\hline C2 & 0,06596 & 0,26183 & 0,13599 & 0,13292 \\
\hline C3 & 0,36945 & 0,22508 & 0,10195 & 0,20390 \\
\hline C4 & 0,21755 & 0,17298 & 0,14087 & 0,17436 \\
\hline C5 & 0,13368 & 0,13041 & 0,18616 & 0,14805 \\
\hline C6 & 0,07509 & 0,09068 & 0,29553 & 0,12625 \\
\hline C7 & 0,05527 & 0,08068 & 0,03525 & 0,05397 \\
\hline
\end{tabular}

Source: Own creation.

In table 3 we can see that the ability to solve problems would be the most important thing to consider in a good leader, since he has obtained the highest score, following the strategic and negotiation capacity and the team-work capacity. What has become less relevant, although all these characteristics are important in a good project team leader, is adaptability and empathy. 


\section{CONCLUSIONS}

After the entire research process and the calculation process to establish a hierarchy, it is observed, as we have seen in the previous point, that the ability to solve problems is the most important characteristic that we must have in mind in a good project leader. And they follow the following qualities being the last empathy.

All these qualities are important in a good project leader. It is important to remember that in this document the most important qualities have been identified and within them their hierarchy.

The order of these qualities is as follows:

- First place: Ability to solve problems.

- Second place: Strategic and negotiation capacity.

- Third place: Team-work capacity.

- Fourth place: Ability to lead.

- Fifth place: Charisma.

- Sixth place: Adaptability.

- Seventh place: Empathy.

It makes sense that the result of the study has been in first place one of the basic skills of the leader who is his ability to solve problems. Problems are part of the dynamics and daily life of organizations and leaders need to know how to deal with them and what decisions to make to solve them. This is a very practical aspect of leadership; problems are part of the situations that the leader has to manage.

The key to handling problems when they arise is having the right perspective. They can be seen as a threat or as an opportunity. So, when a leader sees difficulties, he not only thinks about problems, he must also think about opportunities.

But it is important to distinguish when faced with a problem or an opportunity. It is not always clear, and this is very important for the management of the leader

Peter F. Drucker, What Makes An Effective Executive, Harvard Business Review (2004) says that "Solving a problem simply restores normalcy, but progress necessarily comes from exploiting opportunities" and the aforementioned author adds: A problem is that which jeopardizes the organization's ability to achieve its objectives, and when they appear, they must be resolved; but the opportunity is that which offers the possibility of exceeding the objectives. Another important aspect when solving problems is the support and participation of the work team. In some work contexts the leader is seen as fixing everything. But not all decisions in response to problems must correspond to the leader.

The leader needs to prioritize what problems require more attention. This will help your decisions focus on the core of the real problems and needs, concentrating your energy, attention and time to solve the problems, instead of diluting yourself in many problems at once. In addition, there is no leader with the ability to effectively manage all the problems that occur in your organization. The leader needs to identify real crises, potential crises or major opportunities. On the other hand, by allowing others to take the decision to solve a problem, the commitment of those who accompany the leader is strengthened and also learn to take responsibility for the results, whether they are successes or failures. It is necessary to always keep in mind that leaders have the responsibility to enable others to develop their potential, and to consolidate the necessary skills to solve problems.

Another aspect that needs to be emphasized in relation to problem solving is that problem solving requires a strategic approach. This is an essential aspect of the leader's 
effectiveness: his strategic sense in solving problems. The idea is to anticipate the problems and not to surprise the leader. Leaders need to be proactive and learn to identify potential problems and anticipate their resolution even before problems appear.

In this regard, Joel Barker comments, in Five regions of the future: The new paradigm for understanding technology, 2005: "The success of management lies in the ability to conduct an adequate strategic exploration, which is achieved by rejecting the attitude of taking decisions as a reaction to present problems to engage in anticipation of future problems". Therefore, the leader needs to analyse:

If it is proactive, the change can mean an opportunity, but if it is reactive, the change can

Become a tremendous threat.

On the other hand, it should be mentioned that problem solving, adaptation and strategy are three intrinsic skills to any leader and should not be lacking in a project manager. Quoting scientist Stephen Hawking, "intelligence is the ability to adapt to change". During the execution of a project, there are many circumstances that can change, many adverse circumstances that may arise, many problems that must be resolved. A good leader demonstrates his intelligence by being flexible, adapting to the moment and finding different solutions depending on the context.

Another of the most important qualities that have emerged in the investigation is that of negotiating, dealing with stakeholders, that is, with all the figures interested in the project and that, in one way or another, can influence its correct development. Within this group are, in addition to customers, partners, sponsors, investors, suppliers and even the company's employees and directors. The list of groups can be increased depending on the type of projects. Occasionally, unions, associations or even the government itself can become stakeholders of a project. Mediating with all these types of groups is not easy. Each of them has a series of specific characteristics that the leader must know to reach agreements with each of them and achieve the planned objectives. An inefficient negotiation can be the cause of the failure of the project. Negotiating is synonymous with listening, talking, proposing solutions to the conflict of interests and agreeing. An effective negotiation must offer options for both stakeholders to win. That is the difficulty of negotiating. The Project Manager must therefore be a versatile negotiator, capable of adapting to any situation and with essential skills to face the various situations that he will face.

In relation to the result obtained in this area of project management, it would be interesting to review whether it is exactly related to what is stated in the existing literature.

The results are reasonable and adjusted to what experience may indicate, therefore, it is hoped that now being quantified these can become a recommendation for entrepreneurs or project leaders in search of the "ideal" leader.

We can also point out that from the point of view of the methodology used based on the AHP technique, it is possible to have a versatile tool to prioritize attributes, beyond what it means in project leadership, as in this case, also, for example, in the case of education or work, when it comes to generic and specific competencies, often because of their number, time and physical and economic limitations, it is not possible to address and develop in totality, and consequently, it is necessary prioritize them based on the specific function that a person develops. 
In conclusion the Project Leader is one of the essential figures for business projects to come to fruition. This professional assumes a series of key functions among which is to develop the project plan and the strategies to carry it out, coordinate the work team, deal with customers and suppliers, manage risks or continuously evaluate the project with the project. In order to ensure its effective development. In order to perform all the functions assigned to the project manager, it is necessary that throughout his professional career he develops certain skills. And, in addition to the technical knowledge, essential to be able to manage a project effectively, the Project Manager needs to enhance its ability for the organization, its leadership capacity, its communication skills and its negotiation skills.

Finally, leading any kind of activity is not easy, the leader must involve and motivate employees to achieve objectives, inspire confidence in employees, without losing authority. A good leader must be committed in the development of their work to reach the goal set, share knowledge with their employees and learn from them by their experiences.

\section{REFERENCES}

A guide to the project management body of knowledge (PMBOK guide. Newtown Square, PA: Project Management Institute, 2017. Print.

Alexander, M. (2016). Lead or lag: linking strategic project management \& thought leadership. Bellingham, WA: Lead-Her-Ship Group.

Barker, Joel A., Scott W. Erickson (2005). Five regions of the future: the new paradigm for understanding technology. New York: Portfolio. Print.

Bennis, W.G. (2003). On becoming a leader. Cambridge. MA: Perseus Pub. Print.

BON. (2003). Organizational project management maturity model (OPM3): knowledge foundation. Newtown Square, Pa: Project Management Institute.

Chiocchio, François, E.K. Kelloway, Brian Hobbs (2015). The psychology and management of project teams: an interdisciplinary perspective. New York: Oxford University Press. Print.

Cobb, A. (2012). Leading project teams: the basics of project management and team leadership. Thousand Oaks, Calif: SAGE.

DeMarco, T. Lister, T. (1999). Peopleware: productive projects and teams. New York, NY: Dorset House Pub.

Drucker, P.T. (2017). What makes an effective executive. Boston, Massachusetts: Harvard Business Review Press Print.

Duhigg, C. (2012). The power of habit: why we do what we do in life and business. New York: Random House.

Ellis, C., Smith, J., Saw, M. (2016). The conscious project leader: how to create a culture of success for your projects, your team and yourself. Clifton Hill, Vic: Colin D Ellis.

Haugan, G. (2008). Work breakdown structures for projects, programs, and enterprises. Vienna, VA: Management Concepts.

Isaacson, W. (2014). Steve Jobs: lecciones de liderazgo. Barcelona: Debate.

Jenner, S., Kilford, C. (2011). Management of portfolios. Norwich: TSO (The Stationery Office. Kerzner, H. (2005). Using the project management maturity model: strategic planning for project management. Hoboken, N.J: John Wiley \& Sons.

Kerzner, H. (2006). Project management: a systems approach to planning, scheduling, and controlling. Hoboken, N.J: J. Wiley.

Kliem, R., Ludin, I., Robertson, K. (1997). Project management methodology: a practical guide for the next millennium. New York: Marcel Dekker. 
Kouzes, J., Posner, B. (2007). The leadership challenge. San Francisco, CA: Jossey-Bass. Lewis, J. (2003). Project leadership. New York: McGraw-Hill.

Malachowsky, S. (2018). Project team leadership and communication. Rochester, NY, USA: Lintwood Press.

Managment (2011). Managing successful programmes. London: TSO (The Stationary Office). Martínez, Eliseo, Salvador Rizo (1999). El Proyecto y su dirección y gestión. Valencia: Universidad Politécnica de Valencia, Servicio de Publicaciones. Print.

Maxwell, J. (2006). Las 21 leyes irrefutables del liderazgo. Nashville, TN: Lider Latino.

Mc Graw-Hill. (1996). McConell, S. Desarrollo y gestión de proyectos informáticos. Capítulo 11: Motivación.

McGregor, D. (1960). The human side of enterprise. New York: McGraw-Hill.

Michalko, M. (2006). Thinkertoys : a handbook of creative-thinking techniques. Berkeley, Calif: Ten Speed Press.

Palomo, M.T., Liderazgo y motivación de equipos de trabajo. Capitulo 2: La motivación. ESIC Editorial. 2000.

Miguel Ángel Sánchez Romero; Pablo Aragonés Beltrán; Mª Carmen González-Cruz; Juan Pascual Pastor Ferrando (2011). Cuestiones y Problemas Resueltos de Direccióin de Proyectos. Universitat Politécnica de Valéncia.

Peris Blanes, J., Jorge Alcaide Marzal, Monica Garcia Melon, Pastor, J.P., Gómez, T., Ferrer, P. Ferrero, G. (2002). Teoria y Proceso del Proyecto. Apuntes. Editorial UPV. SPUPV 2002.947. PM. (2013). The standard for program management. Newtown Square, Pa: Project Management Institute.

Prince2 (2009). Managing successful projects with PRINCE2. London: TSO.

Prusak, A., Strojny, J., Stefanow, P. (2015). Zastosowanie metody AHP w badaniu satysfakcji klienta urzędu administracji publicznej [w:] Dziadkowiec, J., Sikora, T., red., Wybrane aspekty zarządzania jakościa ustug. Kraków: Uniwersytet Ekonomiczny w Krakowie.

Riepma, R., Hedeman, B., Aken, T. (2010). Projectmanagement voor het HBO op basis van IPMA-D. Zaltbommel: Van Haren Publishing.

Rocío Poveda Bautista; Gonzalez Cruz, Maria Carmen; Gomez-Senent Martinez, Eliseo (2007). Fundamentos de la Dirección y Gestión de Proyectos. Universidad Politécnica de Valencia.

Rocío Poveda Bautista; Ma Carmen González Cruz; Eliseo Gómez-Senent Martínez (2008). Fundamentos de la Dirección y Gestión de Proyectos. LIMUSA S.A /Grupo Noriega Editores, de México

Roden, E., Vowler, S. (2013). Portfolio, programme and project offices. London: The Stationery Office.

Saaty, T.L. (1980). Multicriteria Decision Making: The Analytic Hierarchy Process. McGraw Hill. New York.

(1980). The analytic hierarchy process: planning, priority setting, resource allocation. New York London: McGraw-Hill International Book Co. Print.

Schmidt, T. (2009). Strategic project management made simple: practical tools for leaders and teams. Hoboken, N.J: John Wiley \& Sons.

Somervill, B. (2009). Team projects. Chicago: Heinemann Library.

Strojny, J. (2009). Zarzązanie przedsiębiorczością w matej i średniej firmie. Rzeszów: Oficyna Wydawnicza Politechniki Rzeszowskiej. 
(2019). Orientacja procesowo-projektowa organizacji samorzadu lokalnego: wymiary, poziomy dojrzałości, determinanty oraz efekty w zakresie rozwoju lokalnego. Rzeszów: Oficyna Wydawnicza Politechniki Rzeszowskiej.

Strojny, J., Stankiewicz, B. (2009). Wielowymiarowa analiza przedsiębiorczości - metodologia, narzędzia i znaczenie dla spoteczeństwa informacyjnego. „Przedsiębiorczość - Edukacja”, t. 5. Strojny, J., Szulc, J., Baran, M. (2018). Applying the AHP Method into the Assessment of Project Attitudes.

Tracy, B., Pena, J. (2017). Liderazgo. Nashville, TN: Grupo Nelson.

TSO. (2015). PRINCE2 Agile. Norwich UK: TSO (The Stationery Office.

Webster, R. (2010). Management of risk: guidance for practitioners. Norwich: TSO (The Stationary Office).

Wong, Z. (2007). Human factors in project management: concepts, tools, and techniques for inspiring teamwork and motivation. San Francisco: Jossey-Bass.

Zandhuis, A. (2013). ISO 21500 : guidance on project management: a pocket guide. Zaltbommel: Van Haren Pub. Kerzner, H. \& Saladis, F. (2009). Value-driven project management. Hoboken, N.J: Wiley.

DOI: 10.7862/rz.2020.hss.30

The text was submitted to the editorial office: May2020.

The text was accepted for publication: September 2020. 